\title{
First Rovno amber species of the genus Telmatophilus (Coleoptera: Clavicornia: Cryptophagidae) from Veselukha floodplain
}

\author{
G.Yu. Lyubarsky¹, E.E. Perkovsky ${ }^{2,3}$ \\ ${ }^{I}$ Zoological Museum of Moscow State University, Bol'shaya Nikitskaya str., 2, Moscow, 125009 \\ Russia.E-mail:lgeorgy@rambler.ru \\ ${ }^{2}$ Schmalhausen Institute of Zoology, National Academy of Sciences of Ukraine, 15 Bogdan \\ Khmelnitsky Str., Kiev, 01601 Ukraine.E-mail: perkovsk@gmail.com \\ ${ }^{3}$ A.A. Borissiak Paleontological Institute, Russian Academy of Sciences, Profsoyuznaya 123, \\ 117868 Moscow, Russia.
}

ABSTRACT. Telmatophilus sidorchukae Lyubarsky et Perkovsky sp.n. is described from Priabonian Rovno amber, the first Eocene species of the genus. The amber was collected from the Veselukha floodplain in the north-west Rovno region. The new species is similar to the extant Palearctic Telmatophilus typhae, which is an obligate herbivore of Typha flowers. The new species differs from all recent congeners by a combination of: comparatively long antenna with the $3^{\text {rd }}, 4^{\text {th }}$ and $5^{\text {th }}$ antennomeres more than twice as long as wide, $10^{\text {th }}$ antennomere subquadrate, $11^{\text {th }}$ long-oval; distance between the middle coxae half the diameter of the middle coxae; the distance between the metacoxae about five times greater than between the procoxae and approximately equal to the diameter of the posterior coxae. The origin of the genus is linked to the expansion of the helophyte plants on which Telmatophilus species feed, which was apparently facilitated by the appearance of macrophyte lakes in Northern Eurasia after climatic cooling beginning in the second half of the Eocene. Late Priabonian "Telmatophilus" britannicus Kirejtshuk et Kurochkin, 2019 from the Bembridge Marls of the UK is transferred to Cryptophilinae (Erotylidae) as Cryptophilus britannicus (Kirejtshuk et Kurochkin, 2019) comb.n.

How to cite this article: Lyubarsky G.Yu., Perkovsky E.E. 2020. First Rovno amber species of the genus Telmatophilus (Coleoptera: Clavicornia: Cryptophagidae) from Veselukha floodplain // Invert. Zool. Vol.17. No.1. P.25-35. doi: 10.15298/invertzool.17.1.03

KEY WORDS: Cryptophagidae, Telmatophilus, late Eocene, Rovno amber.

\section{Первый ровенский янтарный вид Telmatophilus (Coleoptera: Clavicornia: Cryptophagidae) из поймы Веселухи}

\author{
Г.Ю. Любарский${ }^{1}$, Е.Э. Перковский ${ }^{2,3}$
}

\author{
${ }^{1}$ Зоологический музей МГУ, Большая Никитская 2, Москва 125009 Россия. \\ E-mail:lgeorgy@rambler.ru \\ ${ }^{2}$ Институт зоологии им. И. И. Шмальгаузена НАН Украинь, ул. Б. Хмельницкого, 15, Киев, \\ 01030, Украина.perkovsk@gmail.com \\ ${ }^{3}$ Палеонтологический институт им. А.А. Борисяка РАН, Профсоюзная ул. 123, Москва \\ 117997, Россия.
}


РЕЗЮМЕ. Описан новый вид из позднеэоценового ровенского янтаря: Telmatophilus sidorchukae Lyubarsky et Perkovsky sp.n. Первый эоценовый вид этого рода описан из поймы р. Веселухи (северо-запад Ровенской области). Новый вид сходен с современным палеарктическим видом Telmatophilus typhae, облигатно питающимся на Typha. Новый вид отличается от всех современных представителей этого рода комбинацией признаков: относительно длинные усики (3-й, 4-й и 5-й членики усика более чем в 2 раза длиннее ширины, 10-й членик не поперечный, 11-й удлиненно-овальный); расстояние между средними тазиками вдвое меньше, чем диаметр среднего тазика; расстояние между задними тазиками примерно в 5 раз больше, чем между передними тазиками, примерно равно диаметру заднего тазика. Предполагается, что возникновение рода связано с широким распространением полупогруженных растений, на которых питаются Telmatophilus, которому способствовало появление макрофитных озёр на севере Евразии после начавшегося во второй половине эоцена похолодания. Недавно описанный из Бембриджа (Великобритания) позднеэоценовый вид Telmatophilus britannicus Kirejtshuk et Kurochkin, 2019 перемещен в подсемейство Cryptophilinae (Erotylidae) как Cryptophilus britannicus (Kirejtshuk et Kurochkin, 2019) comb.n. Как цитировать эту статью: Lyubarsky G.Yu., Perkovsky E.E. 2020. First Rovno amber species of the genus Telmatophilus (Coleoptera: Clavicornia: Cryptophagidae) from Veselukha floodplain // Invert. Zool. Vol.17. No.1. P.25-35. doi: 10.15298/invertzool. 17.1 .03

КЛЮЧЕВЫЕ СЛОВА: Cryptophagidae, Telmatophilus, поздний эоцен, ровенский янтарь.

\section{Introduction}

Rovno amber is the southern coeval analogue of the famous Baltic amber (Perkovsky et al., 2007). Nearly all Rovno amber inclusions from the Rovno region that have been studied so far originated from the Klesov deposit and the Horyn River basin (Perkovsky et al., 2010; Perkovsky, 2017), except for new collections from the more western basins of the Styr and Stokhod rivers. These new collections (mostly from Voronki and Velyki Telkovichi) revealed a number of new species of beetles, neuropterans and snakeflies (Perkovsky, Makarkin, 2019; Jałoszyński, Perkovsky, 2019; Legalov et al., 2019; Makarkin, Perkovsky, 2020), and also some Hymenoptera previously recorded from Baltic amber (Perkovsky, Olmi, 2018; Martynova et al., 2019) or from Baltic and Bitterfeld amber (Radchenko, Perkovsky, 2018, 2020).

These new collections include the first silken fungus beetles (Coleoptera: Cryptophagidae) from these localities, which we here determine to be a new species of Telmatophilus. All previ- ous fossil silken fungus beetles are known from the Cretaceous and Eocene. Two Lower Cretaceous monotypic genera were previously described from South China (in shale, Cai, Wang, 2013; Lyubarsky, Perkovsky, 2018a) and Spain (in late Albian El Soplao amber, Peris et al., 2017). Almost all other Cretaceous cryptophagids have been recorded from late Santonian Taimyr amber (Baeomorpha Realm: Gumovsky et al., 2018): Atomariinae Nganasania khetica Zherikhin, 1977 and $N$. taymyrica Lyubarsky et Perkovsky, 2014(Lyubarsky, Perkovsky, 2017a) and Cryptophagini Microticus (Lyubarsky, Perkovsky, 2015) and Ennoticus (Lyubarsky, Perkovsky, 2017b). Moreover, Lebanophytum Kirejtshuk et Azar (Kirejtshuk, Azar, 2008) (originally placed in Cerophytidae, later in Lebanophytidae Kirejtshuk in Kirejtshuk et Azar, 2013), was removed from Elateroidea and placed in the Cryptophagidae by Yu et al. (2019).

Some representatives of subfamily Atomariinae have been recorded in Priabonian Baltic amber, viz. Atomaria Stephens, 1829, Ephistemus Stephens, 1829, and subfamily Cryptopha- 
ginae, viz., Antherophagus Dejean, 1821, Cryptophagus Herbst, 1792, Micrambe Thomson, 1863, and Telmatophilus Heer, 1841 (Klebs, 1910; Kubisz, 2001); the latter genus is also reported from Bitterfeld amber (Hieke, Pietrzeniuk, 1984). Four atomariines and four cryptophagines have been reported so far from Priabonian ambers (Spahr, 1981; Hieke, Pietrzeniuk, 1984; Lyubarsky, Perkovsky, 2010, 2011, 2012, 2013, 2014, 2018, 2019a; Perkovsky, Lyubarsky, 2014), including the first extinct Eocene monotypic genus Spaniophagus Lyubarsky et Perkovsky, 2019 (Lyubarsky, Perkovsky, 2019b).

Recently a new late Priabonian species was described: "Telmatophilus" britannicus Kirejtshuk et Kurochkin, 2019 (Kirejtshuk et al., 2019) from the Bembridge Marls, UK (see below).

\section{Materials and methods}

The amber was collected in the floodplain of the Veselukha River, specifically from the amber-bearing zone $12 \mathrm{~km}$ long and 5-6 km wide that starts $8 \mathrm{~km}$ north of the village of Ozertsy (Vladimirets district) and reaches the village of Rudki (Zarechnoye district). The sample was cut from the larger, clear piece of amber LKV$875 \times 39 \times 31 \mathrm{~mm}$, weighing $34.2 \mathrm{~g}$, which also included stellate hairs.

Photographs were taken at the Paleontological Institute, Russian Academy of Sciences (Moscow) by A.P. Rasnitsyn using a Leica MZ 16 microscope and by D.D. Vorontsov using a Nikon E-800 microscope; brightfield and incident illumination were combined. Stacks of images, comprising multiple focal planes, were obtained with Olympus OM-D E-M10II digital camera. Images were corrected for colour, brightness and noise with Adobe Lightroom. Figures herein contain layered (multifocal) images from 10 to 40 focal planes processed with Helicon Focus 7.5.8 using algorithm B.

Amber pieces were cut and polished by the protocols of Sidorchuk $(2011,2013)$ with tools described by E.A.Sidorchuk and D.D.Vorontsov (Sidorchuk, Vorontsov, 2018). All of the mate- rial is housed in the amber collection of the Schmalhausen Institute of Zoology of National Academy of Sciences of Ukraine (SIZK) .

\section{Systematic paleontology}

Family Cryptophagidae Kirby, 1826

Subfamily Cryptophaginae Kirby, 1826

Tribe Cryptophagini Kirby, 1826

Genus Telmatophilus Heer, 1841

\section{Telmatophilus sidorchukae sp.n. Figs 1, 2.}

MATERIAL. Holotype, SIZK No LKV-35, Rovno amber, Priabonian. Sex of the holotype: unknown. Syninclusions SIZK No LKV-32: 2 Diptera (Phoridae, Sciaroidea); SIZK No LKV33: 2Collembola, Symphypleona; SIZK No LKV-34: Coleoptera, Collembola (Entomobryomorpha); SIZKNoLKV-36: Collembola(Symphypleona); SIZK No LKV-37: Coleoptera, Collembola (Entomobryomorpha); SIZK No LKV38: 2 Acari; SIZK No LKV-39: Collembola (Entomobryomorpha); SIZK No LKV-40: Collembola (Symphypleona), Acari; SIZK No LKV41:2Collembola (Symphypleona), 2Acari; SIZK No LKV-42: Acari; SIZK No LKV-43: Diptera (Keroplatidae); SIZK No LKV-44: Acari (Oribatei); SIZK No LKV-45: Psocoptera.

DIAGNOSIS. This new fossil species differs from extant congeners by a combination of: small body size; comparatively long antenna, $3^{\text {rd }}, 4^{\text {th }}$ and $5^{\text {th }}$ antennomeres more than twice as long as wide, $10^{\text {th }}$ antennomere not transversal, $11^{\text {th }}$ long-oval; distance between middle coxae half diameter of middle coxae; distance between metacoxae about five times as wide as between procoxae, approximately equal to diameter of posterior coxa.

DESCRIPTION. 1.7 mm long. Body black, elongate oval, parallel-sided, moderately convex dorsally, subflattened ventrally; covered with confused puncturation; short, decumbent pubescence (Figs 1A, 2).

Head with slightly convex anterior margin, comparatively large and prominent eyes, without frontoclypeal suture. Antennae about one 

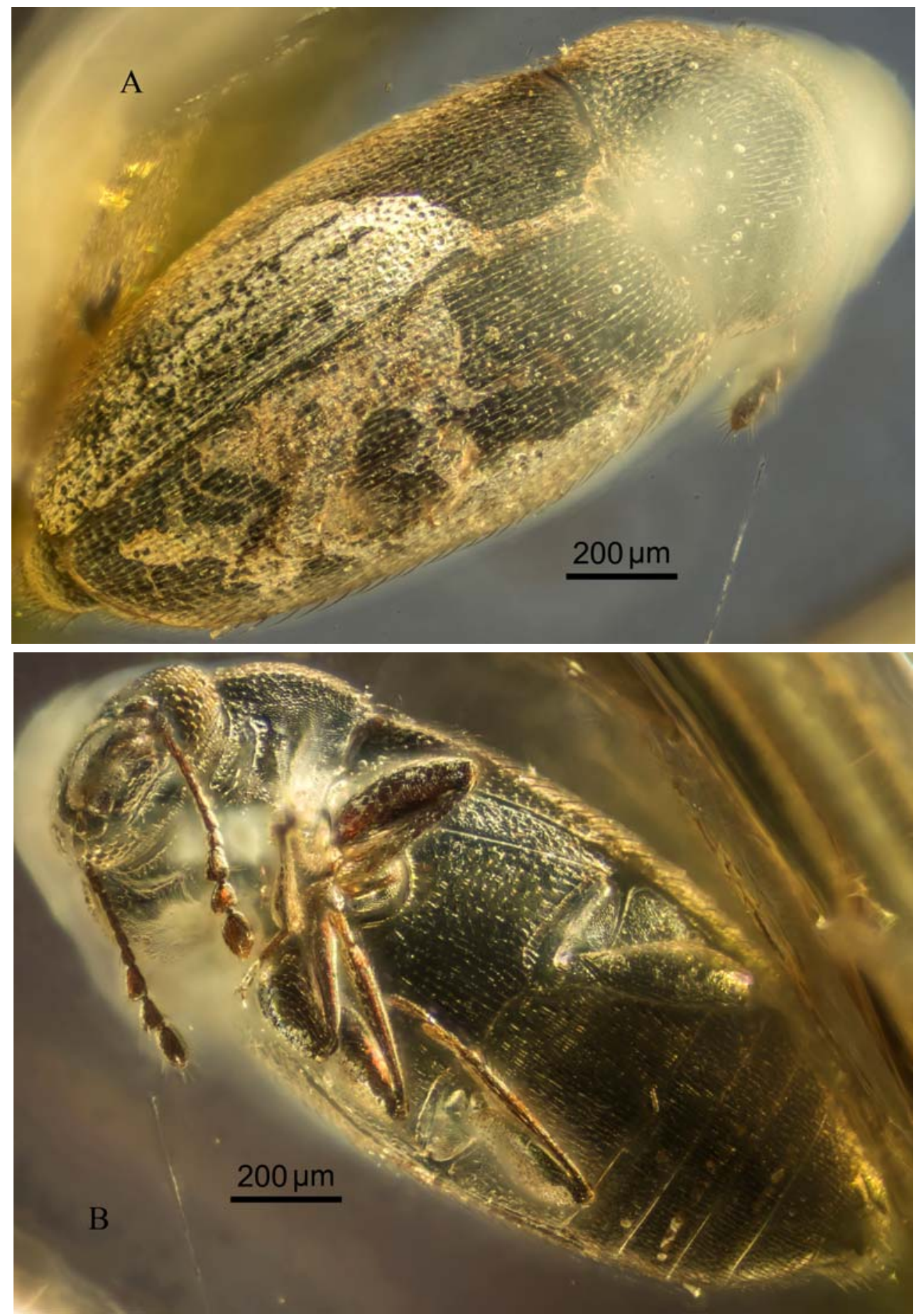

Fig. 1. Telmatophilus sidorchukae sp.n. (photo).

A - total view, dorsal; B - total view, ventral; C - total view, lateral; D - meso- and metathorax.

Рис. 1. Telmatophilus sidorchukae sp.n., фото.

A — общий вид, дорзально; В — общий вид, вентрально; C — общий вид, латерально; D — средне- и заднегрудь. 

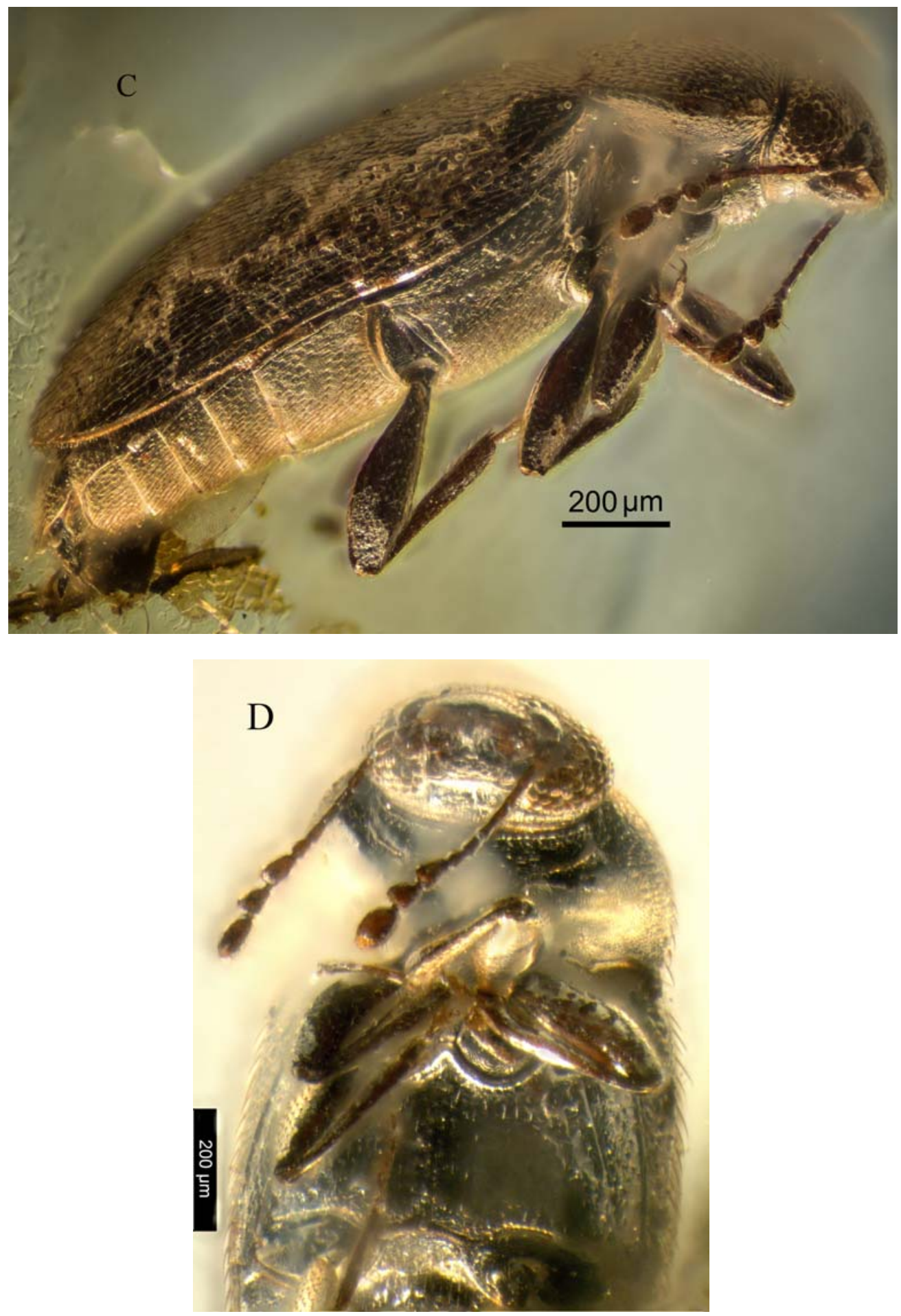

Fig. 1 (continued).

Рис. 1 (продолжение). 


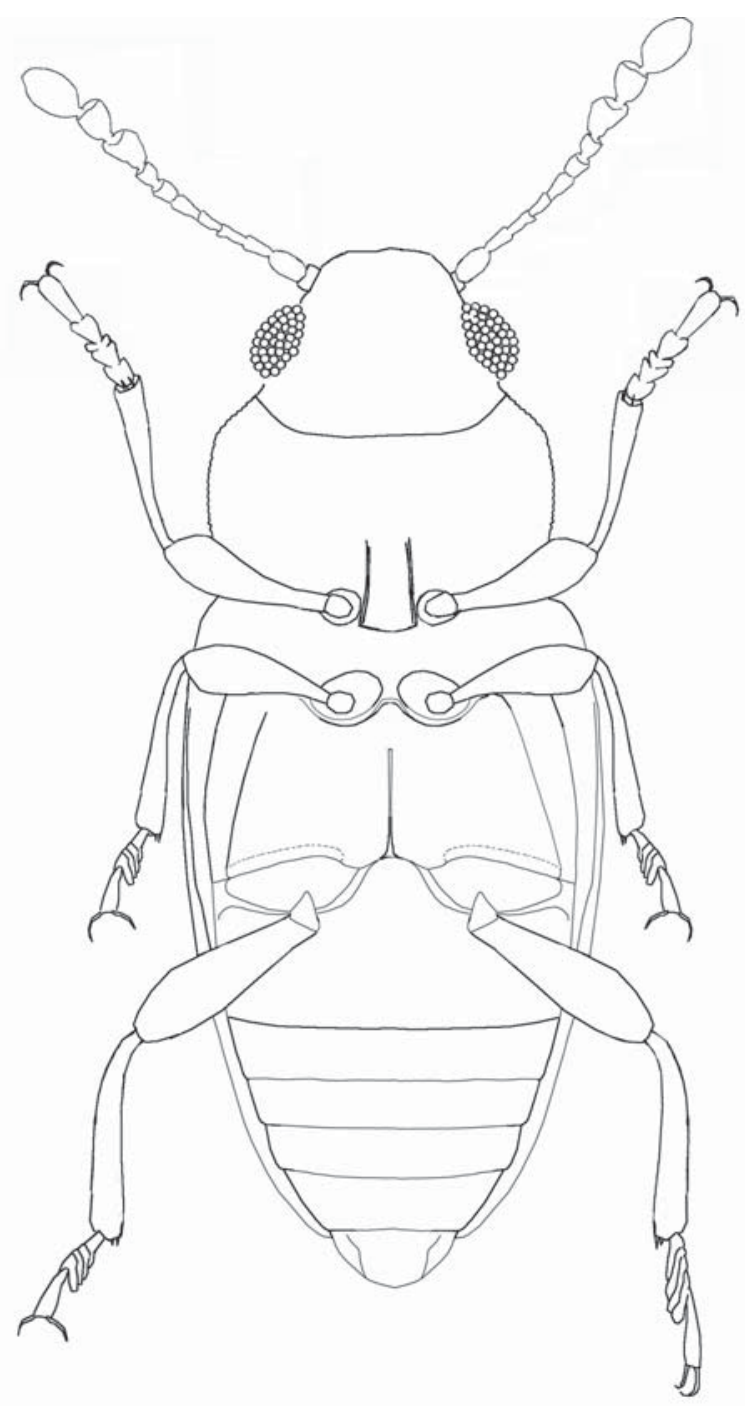

Fig. 2. Telmatophilus sidorchukae sp.n.

Total view, ventral, line drawings.

Рис. 2. Telmatophilus sidorchukae sp.n.

Общий вид, вентрально.

and a third as long as head width, about 2.5 times as long as antennal club, reaching base of pronotum. $1^{\text {st }}$ antennomere oval, 1.6 times as long as wide, $2^{\text {nd }}$, in 1.4 times as long as wide, $3^{\text {rd }}, 4^{\text {th }}$, and $5^{\text {th }}, 2$ times as long as wide, $6^{\text {th }}, 1.7$ times as long as wide, $7^{\text {th }}, 1.5$ times as long as wide, $8^{\text {th }}$ subquadrate, club 3-segmented, elongate, slightly loose, consisting of comparatively large, not transverse segments: $9^{\text {th }}$ antennomere elongated trapezoid, 1.3 times as long as wide, $10^{\text {th }}$ antennomere subquadrate, $11^{\text {th }}$ elongated oval, 1.8 times as long as wide (Fig. 1B).

Pronotum about 1.7 times as wide as long, greatest width at posterior third of its length, arcuately narrowing both anteriorly and posteriorly, gently sloping at sides, anterior margin straight, anterior angles rounded, lateral margin evenly weakly serrate, posterior angles almost 
pointed, posterior margin slightly concave, with weak median lobes. Pronotum without sublateral lines, median fold. Pronotal basal pits present, connected by a groove. Prosternum moderately long, with process comparatively wide, somewhat narrower than antennal club, subparallelsided, truncate, slightly widened at apex. Procoxae closed posteriorly, oval and slightly transverse. Metasternal projection almost reaching middle of length of middle coxa. Distance between middle coxae twice less than diameter of middle coxa (Fig. 1B,D). Metasternum with median longitudinal line. Metaventrite about as long as prosternum, mesoventrite combined, its posterior edge between coxae angulate. Distance between metacoxae about five times as wide as that between procoxae, approximately equal to diameter of posterior coxa (Fig. 1D). Tarsomeres distinctly lobed, tarsal formula 555.

Elytra about 1.6 times as long as wide combined, slightly arcuate at sides, slightly wider than pronotum, apparently gently sloping at sides, their apices seeming to together forming a single arc. Epipleura moderately narrow, reduced, almost reaching $1^{\text {st }}$ ventrite of abdomen.

Ventrite 1 almost as long as ventrites 2-4 combined (Fig. 1C); hypopygidium widely rounded at apex. Hypopygidium protrudes from under the elytra; this sometimes occurs in $\mathrm{Tel}$ matophilus, especially often in females.

ETYMOLOGY. The new species is named in honor of Ekaterina A. Sidorchuk.

REMARKS. In one species of the genus ( $T$. americanus LeConte), there is sexual dimorphism in leg morphology, in particular in the hind tibia. However, European species of the genus developing on cattails do not have this dimorphism precluding determination of the sex of the amber specimen.

\section{Discussion}

The genus Telmatophilus has been previously reported in Baltic and Bitterfeld ambers (Klebs 1910; Barthel, Hetzer, 1982; Hieke, Pietrzeniuk 1984); however, these specimens were never named and these determinations need to be confirmed. Recently "Telmatophilus" bri- tannicus Kirejtshuk et Kurochkin, 2019 (Kirejtshuk et al., 2019) was described from Priabonian Bembridge Marls (Bembridge, 34 Mya), a bit younger than the Priabonian amber deposits (Ross, Self 2014; Tolkanits et al. 2018 and references therein). "T." britannicus as described (Kirejtshuk et al., 2019) is yellow and has a full epipleuron reaching the apex of the elytra ("Epipleura moderately narrow, slightly narrowing apically and almost reaching apices of elytra": Kirejtshuk et Kurochkin, 2019: 67). These diagnostic characters place the specimen in the family Erotylidae (Leschen, 2003: 29). This species also has a prosternum with a relatively short space in front of the coxa; elytral epipleuron complete to the apex of the elytron; prothorax parallel-sided and widest at middle; small body; light coloration; pronotal anterior angles angular and slightly protruding; and the lateral edges of pronotum are arcuate. By these character states, we transfer Telmatophilus britannicus Kirejtshuk et Kurochkin, 2019 to Erotylidae Latreille 1802, tribe Cryptophilini Casey, 1900, genus Cryptophilus Reitter, 1874: Cryptophilus britannicus (Kirejtshuk et Kurochkin, 2019) comb.n.

Telmatophilus sidorchukae sp.n. is then the first species of the genus Telmatophilus described from Eocene.

The new species looks most like $T$. typhae (Fallén, 1802) because of its comparatively long $9^{\text {th }}$ and $10^{\text {th }}$ antennomeres, but differs by the length of its $3-5^{\text {th }}$ antennomeres and the structure of its meso- and metathorax.

As already mentioned, the new fossil species differs from recent congeners by a combination of small body size, comparatively long of antenna, the $3^{\text {rd }}$ antennomere more than twice as long as wide, the $10^{\text {th }}$ antennomere not transverse $11^{\text {th }}$ long-oval, and the distance between the middle coxae half the diameter of the middle coxa.

Extant Holarctic species of this genus are associated with aquatic plants, particularly Typha and Sparganium. The transition to obligatory feeding on flowers is rather infrequent in Cryptophagidae (Leshen, 1996); besides Telmatophilus, this is only known in one genus of 
Atomariinae from the South Hemisphere (Leshen, 1996). A transition to phytophagy from mycetophagy may sometimes occur within a genus: among the many species of Atomaria, nearly all are mycetophagous, but Atomaria linearis Steph. feeds on sugar beet. Episodic feeding on flowers is also known for a number of other genera, including Mnioticus (Leshen, 1996) from the mountains of East Africa. Mnioticus is related to Telmatophilus (Leshen, 1996), as well as to the Santonian genus Microticus from the Kheta Formation of Taimyr. The distribution of angiosperms in the Santonian of Taimyr appears to have been rather limited (Nadein, Perkovsky, 2018), and angiosperm pollen is relatively rare there (less than $10 \%$, according to Kara-Murza, 1960). Therefore, it seems highly unlikely that Microticus fed on flowers.

Species of Telmatophilus are found in quite different habitats: in flowers of marsh marigold, Caltha palustris (Ranunculaceae); in the flowers of Umbelliferae; in the reed Phragmytes; under bark; on willow; or on sedge. The seasonal history and habits of T. typhae was summarized by Hoebecke \& Wheeler (2000). T. typhae in N. America is found on Typha latifolia and Typha angustifolia (introduced from Europe). Both larvae and adults of Telmatophilus feed on the semi-aquatic plants Sparganium (Sparganiaceae) and Carex (Cyperaceae) as well as Typha (Typhaceae). Overwintered females of $T$. typhae lay eggs on the outer surface of immature male Typha inflorescences in late May (Hoebecke, Wheeler, 2000). The eggs hatch in about 3-4 days and the emerging larvae burrow into the flowers to feed. Larval development requires approximately 16-19 days. The first two larval stages feed on immature, succulent stamens and pollen. The final instar larva and adults feed on mature pollen grains. Larvae of all three instars, pupae, and adults are all found on mature male flower clusters. When male flower clusters break up from the central column of the plant, they fall into the standing water along with the beetle larvae and pupae. Pupation occurs by the end of July, requiring about five days, and new adults begin to emerge by mid-August. The life cycle of Telmatophilus (the of T. typhae is the best known) coincides with that of its host plant. This implies that the flowers of Typha are a stable and widespread resource.

The spread of semi-submerged helophyte plants (cattail, bur-reed, sedge) on which Telmatophilus species feed appears to have been facilitated by the appearance of macrophyte lakes during climatic cooling in the second half of the Eocene (Ponomarenko, 2010). Cattails and the other helophyte plants mentioned above have a near-global geographical distribution, while the Telmatophilus species are found only in the Holarctic, and Telmatophilus feeding on Typha (disregarding recent invasions), are only known in the Palearctic. The connection between the ancestors of Telmatophilus switching to feeding on flowers and the geological record of their host plants has been made possible by the publication of a recent revision of the phylogeny and historical biogeography of Typha (Zhou et al., 2018).

Typha is a relatively ancient genus. Both Typha and Sparganium have extensive and distinctive fossil records dating back to the Paleogene, as well as two Maastrichtian records (Zhou et al., 2018). The respective crown ages of Typha and Sparganium were estimated to be 39.03 Mya (95\% HPD: 22.64-57.60 Mya) and 18.03 Mya (5.79-36.69 Mya), respectively (Zhou et al., 2018). The Late Cretaceous and Paleogene fossils differ somewhat from extant Typha species, however, and Zhou et al. (2018) didn't rule out the possibility that these are part of its stem lineage. It appears reasonable that the time of appearance of Telmatophilus matches that of the Typha crown-group, close to Priabonian Baltic, Rovno and Bitterfeld ambers. Molecular dating indicates that the origin of crown-group Typha occurred in Bartonian (middle Eocene); and that it most likely originated in East Eurasia and then dispersed into other areas (Zhou et al., 2018). It may be that the reproductive cycle of the ancestors of Telmatophilus that fed on semi-submerged helophyte plants became connected to colder winters, which prevented the genus from spreading beyond the boundaries of the Holarctic. 
The genus Telmatophilus was revised by Otero (2012), confirming the status of Telmatophilus brevicollis Aubé, 1862, T. caricis (Olivier, 1790) and T. typhae (Fallén, 1802). In this work, he established two new synonymies: Cryptophagus sparganii Ahrens, $1812=$ Telmatophilus caricis (Olivier, 1790) and Cryptophagus schonherrii Gyllenhal, 1808 = Telmatophilus typhae (Fallén, 1802). The larvae of Telmatophilus brevicollis depend on the seeds of Sparganium erectum L.; Telmatophilus caricis lives on Typha sp. and Sparganium sp., in which they grow during June and July. Telmatophilus typhae lives on Typha latifolia L., T. angustifolia L. and other aquatic plants and feeds on pollen.

Occurrences of Telmatophilus in the Palearctic include T. brevicollis (S Europe - Caucasus - Kazakhstan); T. caricis (S Europe - N Africa - Caucasus - Uzbekistan - Siberia Mongolia); T. orientalis Sasaji, 1987 (Kanto (Honshu), Japan); and T. typhae (S Europe - N Africa-Caucasus - Kazakhstan-UzbekistanKyrgyzstan - Siberia - Russian Far East-Hebei (China) - Hokkaido (Japan) - N Korea).

The sole native American species T. americanus feeds only on transboreal species of Sparganium and the arecid Peltandra, while cattails in the Eastern part of North America are fed on by the introduced T. typhae (Hoebecke, Wheeler, 2000). T. americanus does not range south beyond the states of Colorado, Indiana and New York (Majka, Langor, 2010); unlike the Palearctic species, T. americanus does not penetrate to the subtropics. Combined with the Priabonian findings of Telmatophilus in E. and N. Europe and its Palearctic range, this supports the notion of a European or, less likely, extratropical Asian origin of the genus, with a rather late migration into North America (probably via Beringia) of just one boreal species feeding on Sparganium. The lack of other Nearctic species, together with the broad distribution of Typha latifolia in the Nearctic, suggests that at least in Europe the genus first appeared only after the 'De Geer' and 'Thulean' routes through Greenland and Iceland (Archibald et al., 2011) ceased to exist.
The finding of Telmatophilus in the floodplain of the Veselukha (between the Styr and Stokhod basins) rather than in Klesov is further evidence of more extensive wetlands there (as well as in Horyn basin: Perkovsky, Vlaskin, 2005) compared to Klesov. The first amber species of Sphagnum was described from the Styr basin (Ignatov et al., 2019), upon which also various diatoms were found. The occurrences of a number of species shared between Rovno amber from the Styr, Veselukha and Stokhod basins and Baltic amber might be explained by some similarities of their paleoclimates (Martynova et al., 2019). High humidity at the locality of the holotype is further indicated by an unusually large number of collembolans from various suborders (9 specimens) among the syninclusions. Combined with the large size of the amber sample, this abundance of collembolans suggests burial of the resin bearing the holotype near the base of the trunk (Perkovsky et al., 2012 at references therein). It is probable that the wet forest litter near a water body was the habitat of the imago after the end of flowering period of the semi-aquatic host plants near a water body.

Acknowledgements. We are grateful to Nikolay R. Khomich (Rovno) for help with acquiring the sample, Anatoly P. Vlaskin (SIZK) for cutting and primary polishing of the sample, Dmitry D. Vorontsov (Institute of Developmental Biology, Moscow, Russia) and A.P. Rasnitsyn (PIN) for photos, Dmitry D. Vorontsov also for additional polishing and preparation of the sample, S.E. Chernyshev (Institute of Systematics and Ecology of Animals of Siberian Branch of Russian Academy of Sciences, Novosibirsk, Russia) for reviewing the manuscript, and S. Bruce Archibald (Simon Fraser University, Burnaby, Canada) for editing of the English. The study was supported by the research project "Taxonomic and Biochorologic Analysis of the Animal Kingdom as the Basis for the Study and Preservation of the Structure ofBiodiversity (AAAA-A16-116021660077-3)," Zoological Museum of Moscow State University.

\section{References}

Archibald S.B., Johnson K.R., Mathewes R.W., Greenwood D.R. 2011. Intercontinental dispersal of giant thermophilic ants across the Arctic during early Eocene hyperthermals // Proc. R. Soc. B. Vol.278. P.36793686. 
Barthel M., Hetzer H. 1982. Bernstein-Inklusen aus dem Miozän des Bitterfelder Raumes. Zeitschrift für Angewandte Geologie. Bd.28. S.314-336.

Cai C.-Y., Wang B. 2013. The oldest silken fungus beetle from the Early Cretaceous of southern China (Coleoptera: Cryptophagidae: Atomariinae) // Alcheringa. Vol.37. P.1-4.

Gumovsky A., Perkovsky E., Rasnitsyn A. 2018. Laurasian ancestors and "Gondwanan" descendants of Rotoitidae (Hymenoptera: Chalcidoidea): What a review of Late Cretaceous Baeomorpha revealed // Cretaceous Research. Vol.84. P.286-322. https:// doi.org/10.1016/j.cretres.2017.10.027

Hieke F., Pietrzeniuk E. 1984. Die Bernstein-Käfer des Museums fur Naturkunde, Berlin (Insecta, Coleoptera) // Mitt. zool. Mus. Berl. Bd.60. H.2. S.297-326.

Hoebecke E.R., Wheeler G. 2000. Telmatophilus typhae (Fallén) (Coleoptera: Cryptophagidae), a palearctic cattail specialist established in the Canadian Maritime Provinces // Proceedings of the Entomological Society of Washington. Vol.102. P.398-402.

Ignatov M.S., Lamkowski P., Ignatova E.A., Perkovsky E.E. 2019. Mosses from Rovno amber (Ukraine), 4, Sphagnum heinrichsii sp. nov. // Arctoa. Vol.28. No.1. P.1-11.

Jałoszyński P., Perkovsky E.E. 2019. The Mastigitae genus $\uparrow$ Baltostigus in Upper Eocene Rovno amber (Coleoptera: Staphylinidae: Scydmaeninae) // Zootaxa. Vol.4661. No.3. P.594-600. https://doi.org/10.11646/ zootaxa.4661.3.12

Kara-Murza E.N. 1960. [Palynological basis of stratigraphical subdivision of the Mesozoic deposits of the Khatanga Depression]. Leningrad. Gostoptekhizdat. 180 p. [In Russian]

Kirejtshuk A.G., Azar D. 2008. New taxa of beetles (Insecta, Coleoptera) from Lebanese amber with evolutionary and systematic comments // Alavesia. Vol.2. P.15-346.

Kirejtshuk A.G., Azar D. 2013. Current knowledge of Coleoptera (Insecta) from the Lower Cretaceous Lebanese amber and taxonomical notes for some Mesozoic groups // Terrestrial Arthropod Reviews. Vol.6. P.103-134.

Kirejtshuk A.G., Ponomarenko A.G., Kurochkin A.S., Alexeev A.V., Gratshev V.G., Solodovnikov A.Yu., Krell F.-Th., Soriano C. 2019. The beetle (Coleoptera) fauna of the Insect Limestone (late Eocene), Isle of Wight, southern England // Earth and Environmental Science Transactions of the Royal Society of Edinburgh. P.1-88.

Klebs R. 1910. Uber Bersteineinschlüsse im allgemeinen und die Coleopteren meiner Bernsteinsammlung // Schriften der physikalisch-ökonomischen Gesellschaft zu Königsberg i Pr. Bd.5. S.217-242.

Kubisz D. 2001. Beetles in the collection of the Museum of Amber Inclusions, University of Gdańsk, with description of Colotes sambicus sp. n. (Coleoptera: Melyridae) // Polskie Pismo Entomologiczne. Vol.70. P.259-265.

Legalov A.A., Nazarenko V.Yu., Perkovsky E.E. 2019. New weevils (Coleoptera: Curculionidae) from Rovno amber // Paleontol. J. Vol.53. No.10. P.56-60.

Leschen R.A.B. 1996. Phylogeny and revision of the genera of Cryptophagidae (Coleoptera: Cucujoidea) // Kansas Science Bulletin. Vol.55. P.549-634.

Leschen R.A.B. 2003. Erotylidae (Insecta: Coleoptera: Cucujoidea): phylogeny and review. Fauna of New Zealand. Vol.47. 108 pp.

Lyubarsky G.Yu., Perkovsky E.E. 2010. The first Eocene species of the genus Micrambe (Coleoptera, Clavicornia, Cryptophagidae)//Vestnik zoologii. Vol.44. No.3. P. 275-279.

Lyubarsky G.Yu., Perkovsky E.E. 2011. Third contribution on Rovno amber silken fungus beetles: a new Eocene species of Cryptophagus (Coleoptera, Clavicornia, Cryptophagidae) // ZooKeys. Vol.130. P.255261.

Lyubarsky G.Yu., Perkovsky E.E. 2012. The first Eocene species of the genus Cryptophagus (Coleoptera, Clavicornia, Cryptophagidae) // Vestnik zoologii. Vol.46. No.1. P.83-87.

Lyubarsky G.Yu., Perkovsky E.E. 2013. Fourth contribution on Late Eocene amber silken fungus beetles: a new Baltic amber species of Atomaria (Coleoptera, Clavicornia, Cryptophagidae) // Vestnik zoologii. Vol.47. No.3. P.63-66.

Lyubarsky G.Yu., Perkovsky E.E. 2014. New species of the genus Nganasania from Upper Cretaceous of Taymyr (Coleoptera: Cryptophagidae) // Russian Entomol. J. Vol.23. No.3. P.191-194.

Lyubarsky G.Yu., Perkovsky E.E. 2015. New genus Microticus from Upper Cretaceous of Taymyr (Coleoptera: Cryptophagidae), oldest silken fungus beetle with sexually dimorphic tarsal formula // Russian Entomol. J. Vol.24. No.1. P.61-66.

Lyubarsky G.Yu., Perkovsky E.E. 2017a. New genus Ennoticus from the Upper Cretaceous of Taimyr (Coleoptera: Cryptophagidae)//Paleontologicheskii Zhurnal. No.2. P.81-85 [in Russian; English translation: Paleontol. J. Vol.51. No.2. P.191-195.]

Lyubarsky G.Yu., Perkovsky E.E. 2017b. Re-description of the genus Nganasania Zherikhin, 1977 from Upper Cretaceous of Taimyr (Coleoptera: Cryptophagidae) // Russian Entomol. J. Vol.26. No.3. P.251-255.

Lyubarsky G.Yu., Perkovsky E.E. 2018. First species of Atomaria (Coleoptera: Clavicornia: Cryptophagidae) from Bitterfeld amber and several notes on Miocene and Cretaceous Cryptophagidae // Russian Entomol. J. Vol.20. No.4. P.381-385.

Lyubarsky G.Yu., Perkovsky E.E. 2019a. First species of Ephistemus (Coleoptera: Clavicornia: Cryptophagidae) from Baltic amber // Russian Entomol. J. Vol.28. No.1. P.54-57.

Lyubarsky G.Yu., Perkovsky E.E. 2019b. Spaniophagus, first new Eocene genus of silken fungus beetle from Baltic amber (Coleoptera: Clavicornia: Cryptophagidae) // Russian Entomol. J. Vol.28. No.3. P.263-268.

Majka Ch.G., Langor D. 2010. Contributions towards an understanding of the Cryptophaginae (Coleoptera, Cryptophagidae) of Atlantic Canada // ZooKeys. Vol.35. P.13-35. 
Makarkin V.N., Perkovsky E.E. 2020. A new species of Proneuronema (Neuroptera: Hemerobiidae) from late Eocene Rovno amber // Zootaxa. Vol.4718. No.2. P.292-300.

Martynova K.V., Perkovsky E.E., Olmi M., Vasilenko D.V. 2019. New records of Upper Eocene chrysidoid wasps (Hymenoptera: Chrysidoidea) from basins of Styr and Stokhod rivers (Rovno amber) // Paleontol. J. Vol.53. No.10. P.998-1023.

Nadein K.S., Perkovsky E.E. 2018. A new tribe of Galerucinae leaf beetle (Insecta: Coleoptera: Chrysomelidae) from the Upper Cretaceous Taimyr amber // Cretaceous Res. Vol.84. P.97-106. https://doi.org/ 10.1016/j.cretres.2017.10.023.

Otero J.C. 2012. Telmatophilus Heer, 1841 (Coleoptera: Cryptophagidae) of western Palaearctic region // Entomologica Fennica. Vol.23. P.113-120.

Peris D., Lyubarsky G.Yu., Perkovsky E.E. 2017. A new genus of silken-fungus beetle (Coleoptera: Cryptophagidae) from the Spanish Cretaceous amber // Cretaceous Research. Vol.78. P.191-195.

Perkovsky E.E. 2017. Comparison of biting midges of the Early Eocene Cambay amber (India) and Late Eocene European ambers supports the independent origin of European ambers // Vestnik zoologii. Vol.51. No.4. P.275-284.

Perkovsky E.E., Lyubarsky G.Yu. 2014. Fifth contribution on silken fungus beetles from Late Eocene amber: a second Baltic amber species of Atomaria (Coleoptera: Clavicornia: Cryptophagidae) // Russian Entomol. J. Vol.23. No.1. P.41-44.

Perkovsky E.E., Makarkin V.N. 2019. A new species of Succinoraphidia Aspock \& Aspock, 2004 (Raphidioptera: Raphidiidae) from the late Eocene Rovno amber, with venation characteristics of the genus // Zootaxa. Vol.4576. No.3. P.70-580. https://doi.org/ 10.11646/zootaxa.4576.3.9

Perkovsky E.E., Olmi M. 2018. Discovery of the first pincer wasp (Hymenoptera, Dryinidae) from Rovno amber // Zootaxa. Vol.4457. No.2. P.296-304. https:/ /doi.org/10.11646/zootaxa.4457.2.5

Perkovsky E.E., Rasnitsyn A.P., Vlaskin A.P., Taraschuk M.V. 2007. A comparative analysis of the Baltic and Rovno amber arthropod faunas: representative samples // African Invertebrates. Vol.48. No.1. P.229-245.

Perkovsky E.E, Rasnitsyn A.P., Vlaskin A.P., Rasnitsyn S.P. 2012. Contribution to the study of the structure of amber forest communities based on analysis of syninclusions in the Rovno Amber (Late Eocene of Ukraine) // Paleontologicheskii Zhurnal. No.3. P.70-78 [in Russian; English translation: Paleontol. J. Vol.46. P.293-301]. doi:10.1134/S0031030112030136

Perkovsky E.E., Vlaskin A.P. 2005. First comparison of share of some dipteran and hymenopteran families from late Eocene Rovno amber collected at Klesov and Dubrovitsa // P.F. Gozhik (ed.). Biostratigraphic criteria of dissection and correlation of sediments y of Phanerozoic of Ukraine. Kiev: Gnosis. P.250-251 [in Russian with English abstract].
Perkovsky E.E., Zosimovich V.Yu., Vlaskin A.P. 2010. Rovno Amber // D. Penney (ed.). Biodiversity of fossils in amber from the major world deposits. Manchester: Siri Scientific Press, P.116-136.

Ponomarenko A.G. 2010. Arthropods in the evolution of continental water bodies // Vest. Ross. Akad. Nauk. Vol.80. No.10. P.880-889.

Radchenko A.G., Perkovsky E.E. 2018. First record of fossil ant species Eocenomyrma rugosostriata (Mayr) (Hymenoptera: Formicidae) from the Rovno amber // Russian Entomol. J. Vol.27. No.3. P.285-288.

Radchenko A.G., Perkovsky E.E. 2020. New records of the fossil ant genus Prionomyrmex Mayr (Hymenoptera, Formicidae, Myrmeciinae) from Late Eocene European ambers // Paleontol. J. Vol.54 (in press).

Ross A.J., Self A. 2014. The fauna and flora of the Insect Limestone (late Eocene), Isle of Wight, UK: introduction, history and Geology // Earth and Environmental Science Transactions of the Royal Society of Edinburgh. Vol.104. P.232-244.

Sidorchuk E.A. 2011. Preparation of six-sided microsamples of Baltic amber for study of organismal inclusions // Z.V. Kostyashova (ed.). Amber Mining and Processing in Sambia, 12-14 May 2010. International Symposium Materials, Kaliningrad. P.47-53.

Sidorchuk E.A. 2013. New technique for preparation of small-sized amber samples with application to mites // D. Azar, M.S. Engel, E. Jarzembowski, L. Krogmann, A. Nel, J.A. Santiago-Blay (eds.). Insect Evolution in an Amberiferous and Stone Alphabet. Proceedings of the 6th International Congress on Fossil Insects, Arthropods and Amber, Leiden-Boston: Brill. P.189201.

Sidorchuk E.A., Vorontsov D.D. 2018. Preparation of small-sized 3D amber samples: state of the technique //Palaeoentomology. Vol.1.P.80-90.http://dx.doi.org/ 10.11646/palaeoentomology.1.1.10

Spahr U. 1981. Systematischer Katalog der Bernstein- und Kopal-Käfer (Coleoptera) // Stuttgarter Beiträge zur. Naturkunde Ser.B. Bd.80. S.1-107.

Tolkanitz V.I., Perkovsky E.E. 2018. First record of the Late Eocene ichneumon fly Rasnitsynites tarsalis Kasparyan (Ichneumonidae, Townesitinae) in Ukraine confirms correlation of the Upper Eocene Lagerstätten // Paleontol. J. Vol.52. P.31-34. 10.1134/ S0031030118010136

Yu Y., Slipinski A., Lawrence J.F., Yan E., Dong R., Pang H. 2019. Reconciling past and present: Mesozoic fossil record and a new phylogeny of the family Cerophytidae (Coleoptera: Elateroidea) // Cretaceous Research. Vol.99. P.51-70.

Zhou B., Tu T., Kong F., Wen J., Xu X. 2018. Revised phylogeny and historical biogeography of the cosmopolitan aquatic plant genus Typha (Typhaceae) // Scientific Reports. Vol.8. No.8813. DOI:10.1038/ s41598-018-27279-3.

Responsible editor K.G. Mikhailov 